J. Product. \& Dev., 23(3): 627- 652(2018)

\title{
EFFECT OF MAGNETIZATION AND NANO POTASSIUM PARTICLES ON GROWTH, YIELD AND FRUIT QUALITY OF CUCUMBER UNDER PLASTIC HOUSE CONDITIONS
}

\author{
A. I. El-Zawily ${ }^{1}$; M.B.I. El-Sawy ${ }^{1}$; E. M. H. EL-Semellawy ${ }^{2}$ and R. Sh. \\ A. Abd-EL-Ghaffar ${ }^{2}$ \\ 1 Department of Horticulture, Faculty of Agriculture, Kafrelsheikh \\ University, Kafrelsheikh, Egypt. \\ 2 Vegetable Research Department, Horticulture Research Institute, \\ Agriculture Research Center, Giza. Egypt
}

\section{ABSTRACT}

Two experiments were carried out under unheated plastic house conditions during the two seasons of 2014/15 and 2016/17 on cucumber cultivar (Hesham F1 hybrid) at the Protect Agriculture Location, Faculty of Agriculture, Kafrelsheikh University in the first season and at the Experimental Farm, Sakha Horticulture Research Station, Horticulture Research Institute, Agriculture Research Center in the second one, to study the effect of magnetization (control, magnetite, magnetized water and magnetite plus magnetized water), nano potassium particles (bulk 100\% and nano form; 100, 75, 50 and $25 \%$ of recommended rate) and their combined interaction on vegetative growth parameters, fruit yield and its components, fruit quality and leaves chemical content. The results can be summarized as follows:

Cucumber plants treated with magnetite plus magnetized water treatment produced the highest values of vegetative growth parameters, i.e., plant height, number of internodes, number of leaves, number branches, leaf area index and dry matter of the $6^{\text {th }}$ leaf, early and total fruit yield (weight and number), fruit quality; fruit length, diameter, soluble solids content and firmness and leaves chemical content; total green color reading (SPAD), N, P and $K$ compared to nontreated plants (control) which had the lowest values.

As for nano potassium application treatments, 100 and $75 \%$ nano potassium particles followed by bulk potassium form treatments resulted in an increment of abovementioned vegetative growth characters, early and total fruit yields, fruit quality and leaves chemical content, while $25 \%$ nano potassium particles treatment gave the lowest values in both seasons. The combined interaction 
between magnetite plus magnetized water and either 100 or $75 \%$ nano potassium particles followed by bulk potassium form treatments were better than the other combined interactions which gave the highest records of abovementioned characters in both seasons.

Conclusively, it could be recommended that the treatment of combination between magnetite + magnetized water with both of 100 or $75 \%$ nano potassium particles were more suitable for obtaining the largest early and total yields with good fruit quality and more profitable for growers and consumers of cucumber grown in the autumn season inside the plastic houses under Kafrelsheikh conditions and similar areas.

Keywords: Cucumber, Magnetization, Magnetite, Magnetized water, Nano potassium, vegetative growth, fruit quality.

\section{INTRODUCTION}

Cucumber (Cucumis sativus L.) is considered one of the most important vegetable crops belong to the Family Cucurbitaceae, it cultivated either in open field or under protected cultivation for local consumption and exportation at all over the world. Nowadays, Egypt has a great potential for greenhouse and the area has rapidly increased through the last few years, cucumber is ranked the first cash vegetable and commercial crop for local market grown under plastic greenhouse conditions. Egypt has about 40,000 feddans of low plastic tunnels and greenhouse (Abou-Hadid, 2010), Total number was estimated to be 22,000 units, and the majority of them cultivated with cucumber plants with an average yield of $10.68 \mathrm{~kg} / \mathrm{m}^{2}$ according to data of Ministry of Agriculture and Land Reclamation statistics (2016) in Nili season. So, there are a great effort must be done to increase the yield, quality and reducing the amount of mineral fertilizers especially potassium, which is used in large amounts and consequently causes an increase in the product quality of fruits (Usherwood, 1985), increase the production costs and causes the environmental pollution. Under the population pressure in Egypt, the need to provide additional technologies increased productivity and fruit quality per area unit.

The magnetic technology has been investigated since the turn of $19^{\text {th }}$ century; 1980s. The magnetite (magnetic iron) is a natural row rock that has a black or brownish-red color, has hardness scale about 6 mohs, one of two natural row rocks naturally magnetic in the world (Mansour, 2007). The most important factor of magnetite increased plant growth (Sudhakar et al., 2002 
and Al-Said and Kamal, 2005), used as a natural soil improvement products and plays an important role in cation uptake capacity and has a positive effect on immobile plant nutrient uptake, such as $\mathrm{Ca}$ and $\mathrm{Mg}$ (Esitken and Turan , 2004), as well as, increased yield ( El-Hifny et al., 2008), enhancement vegetative growth of different crops ( Ali et al., 2011 on pepper, Shehata et al., 2012 on cucumber and El-Eslamboly and Abdel-Wahab, 2014 on cantaloupe) and increased fruit yield and quality (El-Gizawy et al., 2016 on potato and Khalil and Abou Leila, 2016 on physalis pubescens).

The water treated by pass during a magnetic device has been called magnetized water which was successfully use in agriculture irrigation. The plants became more unattractive model for studying the biological effects of magnetic field (Racuciu and Creanga, 2006).

Magnetized water has three main effects; increasing the leaching of excess soluble salts, lowering soil alkalinity and dissolving slightly soluble salts such carbonates, phosphates and sulphates (Bogatin et al., 1999). Overall, the effect of magnetically treated water depends on the plant species, the pathway length of magnetic field and flow rate (Gabrielli et al., 2001). Many investigators reported that magnetized water treatment increase plant metabolism in terms of photosynthesis and water uptake (Yano et al., 2004), produced a bio stimulation on the initial growth stages and had a simulative effect on seedling growth and development of cucumber (Yiunan et al., 2005), leads to modification of water and its properties such it becomes more energetic and able to flow, prevents harmful metals such as lead and nickel uptake by roots, increase the percentage of nutrient elements uptake; phosphorus, potassium and zinc (Tai et al., 2008), increased essential elements uptake by magnetic treatment in tomato and strawberry plants (Duarte Diaz et al., 1997), reducing irrigation water practices and improvements of water productivity (Maheshwari and Grewal, 2009) and improvements in yield and crop quality (Abdul Qados and Hozyan, 2010), actually change physical and chemical structure properties of water molecule; mainly hydrogen bounding, polarity, reducing surface tension and $\mathrm{pH}$, increase minerals dissolvability and provide adequate nutrients, uniform and hexagonally structured cluster these changes may be capable of affecting plant growth (Maheshwari and Grewal, 2011 and Ali et al., 2014), improved plant growth parameters, i.e., plant height, number of leaves and branches, leaf area index and leaves dry matter percentage (Abou El-Yazied et al., 2012, Al-Obadi et al., 2012, Abd El-All et al., 2013 and Shahin et al., 2016) and gave better yield and greatest fruit quality of cucumber, cowpea, brinjal and lettuce(Shahin et al., 2016, and Surendran et al., 2016). 
New strategy of fertilization depends on using slow or controlled release fertilizers such as nanoparticles technique which have high reactivity; more specific surface area, more density of reactive area, consequently increase reactivity of these areas on the particle surface (Castiglione and Cremonini, 2009). Nanometer scale structures are important in many facts of plant biology as the plant cell walls which have pore diameters ranging from 5 to $20 \mathrm{~nm}$ (Fleischer et al., 1999), potassium is one of the cations in the range of 50 to $150 \mathrm{~mm}$ in the water sector (Malkoti, 1999). So, nanotechnology in agriculture has begun and will continue to increase the development of new materials and smart delivery systems for agrochemicals (Moraru et al., 2003), and change physic-chemical properties compared to their bulk materials (Castiglione and Cremonini, 2009).

Few years ago, some researchers tried to examine the potential of nanotechnology on improving crop productivity, fertilizer use efficiency which remained constant for the past several decades; 30-35, 18-20 and 35-40 \% for $\mathrm{N}, \mathrm{P}$ and $\mathrm{K}$, respectively. Design and development of nano fertilizers could be more soluble or more reactive than their bulk counterparts (Nair et al., 2010). Nano fertilizers particles caused a positive effects included vegetative growth in many crops; cucumber, tomato and cantaloupe (Ekinici et al., 2014; Shams and Morsy, 2014; Tantawy et al., 2016); fruit yield and its components and fruit quality (Ekinci et al., 2014; Ghahremani et al., 2014 and Tantawy et al., 2016), leaves chemical content (Ekinici et al., 2014 and Soliman et al., 2016) and leaves N, P and K content ( Afshar et al., 2012 and Tantawy et al., 2015).

So, the aim of this work was to study the effect of magnetite, magnetized water and nano potassium particles on growth, yield and its components, fruit quality and leaves chemical content of cucumber plant under plastic house conditions.

\section{MATERIALS AND METHODS}

Two field experiments were carried out under unheated plastic house. The first field experiment was conducted at the Protect Agriculture Location, Faculty of Agriculture, Kafrelsheikh University during the autumn season of 2014/15, while the second one was conducted at the Experimental Farm of Sakha Horticulture Research Station, Horticulture Research Institute, Agriculture Research Center during 2016/17 season, to study the effect of magnetite, magnetized water and nano potassium particles on vegetative growth parameters, yield and its components, fruit 
quality and leaf chemical content of cucumber plants (Cucumis sativus L., cv. Hesham F1) which was supplied by Suez Canal of Agricultural and Development Company in both seasons. Soil samples were taken from different locations of the plastic house before transplanting at a depth of 0$30 \mathrm{~cm}$ in both seasons for mechanical and chemical analysis. Determination of available nitrogen, phosphorus and potassium were done according to Jackson (1967). Soil pH was achieved in a 1: 2.5 soil-water suspension according to Black (1965). The obtained results are presented in Table (1).

Cucumber seeds were sown in foam seedling trays (84 cells) on September $4^{\text {th }}$ and $25^{\text {th }}$ in both seasons, respectively. The trays were filled with a mixture of peatmoss and vermiculite $(1: 1 \mathrm{v} / \mathrm{v})$, chemical fertilizers and fungicides were added to the mixture; $300 \mathrm{gm}$ ammonium sulphate, $400 \mathrm{gm}$ calcium superphosphate, $150 \mathrm{gm}$ potassium sulphate, $50 \mathrm{ml}$ nutrient solution as source of micro elements and $50 \mathrm{gm}$ fungicide for each $50 \mathrm{~kg}$ of the peatmoss. After sowing, the trays were covered with black plastic sheet for 48 -72 hours, then moved up to high tables and the irrigation, fertilization and pest management were done as recommended. The seedlings of 21 days old were transferred into the soil of plastic house on September $25^{\text {th }}$ in the first season and October $16^{\text {th }}$ in the second one on double rows in ridges of $30 \mathrm{~m}$ in length and $8.5 \mathrm{~m}$ in width with $0.5 \mathrm{~m}$ plant spacing. The plant density was about 2.35 plants $/ \mathrm{m}^{2}$.

Table (1): Mechanical and chemical analysis of the soil under plastic house before conducting the experiments in 2014/15 and 2016/17 seasons.

\begin{tabular}{|l|c|c|}
\hline \multirow{2}{*}{ Soil properties } & \multicolumn{2}{|c|}{ Seasons } \\
\cline { 2 - 3 } & $\mathbf{2 0 1 4 / 1 5}$ & $\mathbf{2 0 1 6 / 1 7}$ \\
\hline Mechanical analysis: & 22.70 & \\
Sand \% & 29.06 & 15.76 \\
Silt \% & 50.24 & 31.76 \\
Clay \% & clayey & 52.54 \\
Soil textures & 7.8 & Clayey \\
\hline pH $(1: 2.5$ soil: water extract) & 2.49 & 8.4 \\
EC (dS/m $\left.{ }^{-1}\right)$ & & 3.9 \\
Available macro elements (ppm) & 175 & 46 \\
N & 27.7 & 10.0 \\
P & 954.8 & 251 \\
K & \\
\hline
\end{tabular}


The missing plants were replaced by another one at a week after transplanting, all cultural practices; cultivation, irrigation, pests and diseases control... etc., were carried out when it was necessary according to the recommendation of the commercial production of cucumber plastic greenhouse as outlined by Ministry of Agriculture and Land Reclamation (1990).

The experiment included 20 treatments, representing the combinations of four magnetizations (non-magnetic, magnetite, magnetized water and magnetite plus magnetized water) and five nano potassium particles (bulk 100\% and nano form; 100, 75, 50 and $25 \%$ of recommended rate) treatments.

Magnetite (Magnetic iron) was contained $48.8 \% \quad \mathrm{Fe}_{3} \mathrm{O}_{4}, 17.3 \% \mathrm{FeO}$, $26.7 \% \mathrm{Fe}_{2} \mathrm{O}_{3}, 2.6 \% \mathrm{MgO}, 4.3 \% \mathrm{SiO}_{2}$ and $0.3 \% \mathrm{CaO}$, supplied by El-Ahram Company, Giza Governorate, Egypt. Magnetized water was obtained by passing the water throw 1000 gauss magnetron unit, linch diameter, supplied by Nefertary Company, El-Asher of Ramadan, Egypt.

Potassium fertilizer was added at the recommended rate through drip irrigation system, the bulk $(0.28-0.80 \mathrm{um})$ was added as potassium sulphate form $\left(48 \% \mathrm{~K}_{2} \mathrm{O}\right)$ and nano particles $(12.01-33.15 \mathrm{~nm})$ was added as superfeed compound $\left(26 \% \mathrm{~K}_{2} \mathrm{O}\right)$; supplied by Nano Biotechnology Company, Mansoura, Egypt. Potassium treatments are shown in Table (2) according to Ministry of Agriculture and Land Reclamation (1990).

Both of farmyard manure (FYM) and other basic chemical fertilizers were added per $100 \mathrm{~m}^{2}$ during preparation of the soil $\left(1.5 \mathrm{~m}^{3}\right.$ farmyard manure, $20 \mathrm{~kg}$ Ammonium sulphate $(20.5 \%, \mathrm{~N}), 20 \mathrm{~kg}$ Calcium superphosphate $\left(15.5 \%, \mathrm{P}_{2} \mathrm{O}_{5}\right), 10 \mathrm{~kg}$ Potassium sulphate $\left(48 \%, \mathrm{k}_{2} \mathrm{O}\right), 5 \mathrm{~kg}$ Magnesium sulphate $(23 \%, \mathrm{MgO})$ and $5 \mathrm{~kg}$ Sulphur). The other recommended chemical fertilizers of $\mathrm{N}, \mathrm{P}, \mathrm{Mg}$ and some micro-elements were added with drip irrigation system (Fertigation) according to Ministry of Agriculture and Land Reclamation, 1990. Both of farmyard manure (FYM) and other basic chemical fertilizers were added per $100 \mathrm{~m}^{2}$ during preparation of the soil $\left(1.5 \mathrm{~m}^{3}\right.$ farmyard manure, $20 \mathrm{~kg}$ Ammonium sulphate $(20.5 \%, \mathrm{~N}), 20 \mathrm{~kg}$ Calcium superphosphate $\left(15.5 \%, \mathrm{P}_{2} \mathrm{O}_{5}\right), 10 \mathrm{~kg}$ Potassium sulphate $\left(48 \%, \mathrm{k}_{2} \mathrm{O}\right), 5 \mathrm{~kg}$ Magnesium sulphate $(23 \%, \mathrm{MgO})$ and $5 \mathrm{~kg}$ Sulphur). The other recommended chemical fertilizers of $\mathrm{N}, \mathrm{P}, \mathrm{Mg}$ and some micro-elements were added with drip irrigation system (Fertigation) according to Ministry of Agriculture and Land Reclamation, 1990. 
Table (2): Nano potassium particles treatments during 2014/15 and 2016/17 seasons.

\begin{tabular}{|c|c|c|c|c|c|c|}
\hline Treatments & & Bulk & Nano & Nano & Nano & Nano \\
\hline Months & Concentration & & & & & \\
\hline October & $g / m^{3}$ & 750 & - & - & - & - \\
\hline & mmol & 7.6 & 7.6 & 5.7 & 3.8 & 1.9 \\
\hline & Superfeed $\left(\mathrm{l} / \mathrm{m}^{3}\right)$ & - & 0.96 & 0.72 & 0.48 & 0.24 \\
\hline November & $g / m^{3}$ & 1000 & - & - & - & - \\
\hline & mmol & 10.22 & 10.22 & 7.67 & 5.11 & 2.56 \\
\hline & Superfeed $\left(\mathrm{l} / \mathrm{m}^{3}\right)$ & - & 1.28 & 0.96 & 0.64 & 0.32 \\
\hline December & $g / \mathrm{m}^{3}$ & 1500 & - & - & - & - \\
\hline & mmol & 15.33 & 15.33 & 11.50 & 7.67 & 3.83 \\
\hline & Superfeed $\left(1 / \mathrm{m}^{3}\right)$ & - & 1.92 & 1.44 & 0.96 & 0.48 \\
\hline January & $\mathrm{g} / \mathrm{m}^{3}$ & 1500 & - & - & - & - \\
\hline & mmol & 15.33 & 15.33 & 11.50 & 7.67 & 3.83 \\
\hline & Superfeed $\left(\mathrm{l} / \mathrm{m}^{3}\right)$ & - & 1.92 & 1.44 & 0.96 & 0.48 \\
\hline February & $\mathrm{g} / \mathrm{m}^{3}$ & 1000 & - & - & - & - \\
\hline & mmol & 10.22 & 10.22 & 7.67 & 5.11 & 2.56 \\
\hline & Superfeed $\left(\mathrm{l} / \mathrm{m}^{3}\right)$ & - & 1.28 & 0.96 & 0.64 & 0.32 \\
\hline
\end{tabular}

\section{Data recorded:}

Vegetative growth parameters including plant height $(\mathrm{cm})$, number of branches, number of internodes, number of leaves, leaf area index $\left(\mathrm{dm}^{2}\right)$ and dry matter of the $6^{\text {th }}$ leaf were recorded at 60 days after transplanting of five plants randomly taken per sub-plot. The early and total yield (weight and number) per square meter were calculated for a total of 9 and 28 harvests, respectively. Average fruit weight of marketable and nonmarketable fruits were also recorded in both growing seasons.

Ten fruits from each sub-plot were randomly taken of the third picking (60 days after transplanting), to study fruit length $(\mathrm{cm})$, diameter (mm), soluble solids content according to A.O.A.C. (1980) and firmness $\left(\mathrm{g} / \mathrm{cm}^{2}\right)$. Leaves chemical content; total green color reading (SPAD) for the $6^{\text {th }}$ leaf from the growing top at 45 days after transplanting from five plants randomly chosen from each replicate according to Yadava (1986) and Marquard and Timpton (1987) and N, P and K were determined at 45 days after transplanting according to Pregel (1945), King (1951) and Jackson (1967) method, respectively. Data were tested by analysis of variance 
according to Little and Hills (1972). Duncan's multiple range test was used for comparison the means of treatments (Duncan, 1955).

\section{Economic evaluation:}

For economic evaluation of cucumber yield under different magne tization and nano potassium particles treatments, estimations of treatments cost, cucumber yield, income (crop value), net return and economic efficiency were done. Seasonal depreciation value of framework, plastic sheet, transplants, fertilizers, irrigation network, pesticides and workers were not included in the budget of this study. The estimation of income was done on basis of average sale price during the production period (5000 L.E. / ton for total yield on both seasons). The costs were negated form the overall cash returns in both seasons as the resultant was the net return. Economic efficiency was also calculated according to John and Frank (1987) by using the following equation:

Economic efficiency $=$ Net return (L.E.) $/$ Total cost (L.E.).

\section{RESULTS AND DISCUSSION}

\section{Vegetative growth:}

Data presented in Table (3) show that, the differences in plant height, number of branches, number of leaves, leaf area index and dry matter of the $6^{\text {th }}$ leaf were significantly affected by applying the different magnetization treatments during both seasons. An exception was obtained for number of internodes in both seasons and leaf area index in the first one, where the differences were non-significant. The magnetite plus magnetized water treatment gave an increment in abovementioned characters, followed by magnetized water and magnetite treatments, respectively. In contrast, the lowest values were obtained from nonmagnetic treatment in both seasons. The stimulation of plant growth as affected by the application of magnetite may be due to the encouragement of $\mathrm{N}, \mathrm{P}, \mathrm{K}$ and $\mathrm{Fe}$ and reduction of $\mathrm{Na}$ and $\mathrm{Cl}$ uptake (El-Hifny et al. 2008). In this concern, Shehata et al. (2012) showed that the suitable magnetization treatment increased the absorption and assimilation of nutrients and ameliorated the stress of salinity on photosynthetic activities. Similarly, Maheshwari (2009) who indicated that magnetite treatment reduces the $\mathrm{Na}$ toxicity. Similar point of view with those reported by Ali et al. (2011) on pepper and Shehata et al. (2012) on cucumber 
Regarding the effect of nano potassium particles, data presented in Table (3) reveal that, the differences in vegetative growth parameters, i.e., plant height, number of branches, number of internodes, number of leaves, leaf area index and dry matter content of the $6^{\text {th }}$ leaf were highly significant due to all nano potassium particles treatments in both seasons. 100 and $75 \%$ nano potassium particles, followed by bulk potassium treatments gave more vigorous plants compared to the other treatments, while the smallest ones resulted from $25 \%$ nano potassium treatment in both seasons.

Respecting the positive effect of nano potassium particles on vegetative growth parameters compared with the bulk form, this may be due to utilization of nano fertilizers increase soil fertility over bulk one (Wang, 2008), the large surface area and small size of the nanomaterials could allow to enhance the interaction and efficient uptake of nutrients for crop fertilization (De Rosa et al., 2010), increased reactivity and faster dissolution kinetics (Chahal et al., 2012) and within the plant, cell- to cell transport could be facilitated by the plasmodesmata (Zambryski, 2004). Consequently, nano particles can be used to increase the supply of elements to plant shoots.

The effect of the interaction between magnetization and nano potassium particles treatments on vegetative growth characters was not significant in both growing seasons, an exception was found in the second season as the differences were highly significant. The plants treated with magnetite plus magnetized water treatment and fertilized with both of 100 and $75 \%$ nano potassium particles, followed by bulk potassium treatment tended to give the highest vegetative growth values, while the $25 \%$ nano potassium particles combined with magnetite plus magnetized water treatment had the lowest records, followed by non-magnetic (control) treatment with either 25 or $50 \%$ nano potassium particles.

\section{Fruit yield and its component:}

Data in Table (4) clear that there were a highly significant increases in early fruit weight $/ \mathrm{m}^{2}$, early fruit number, total fruit weight $/ \mathrm{m}^{2}$ and total fruit number in both seasons. Except total fruit number in the second season, without differences and not significant. All magnetization treatments led to increase weight and number of both early and total fruit yields compared to non-magnetic plants in both seasons. The highest records were obtained from plants that treated by magnetite plus magnetized water treatment, followed by magnetized water, magnetite and finally non-treated ones which had the lowest values in both seasons. The positive effect of magnetic treatments on early and total fruit yields may be 
due to the bioenergetics structure excitement, enzymatic stimulation and causing cell pumping which affect the regulation of crucial ions mechanisms such ATP hydrogen pump and the possibly pivotal proteins configuration (De Souza et al., 2006). Similar results were obtained by Ali et al., (2011) on sweet pepper, Shehata et al., (2012) on cucumber and Surendran et al., (2016) on brinjal.

As for the effect of nano potassium particles, data presented in Table (4) show clearly that early fruit weight, early fruit number, total fruit weight and total fruit number $/ \mathrm{m}^{2}$ were significantly affected in both seasons. Therefore, the highest weight and number $/ \mathrm{m}^{2}$ of both early and total fruit yield were recorded from $100 \%$, followed by $75 \%$ nano potassium particles treatments in the first season, while in the second one, $100 \%$ nano potassium particles, followed by bulk treatment gave the highest records of early yield (weight and number), followed by $100,75 \%$ nano potassium particles and bulk treatments for total yield (weight and number) without any significant differences between each other. On the other hand, the lowest values were obtained from plants treated by $25 \%$ nano potassium particles treatment in both seasons. These results may be due to nano particles improve the fertilizer formulations for increased uptake in plant cell and by minimizing nutrient loss, have a high surface area, absorption capacity and controlledrelease kinetics making smart delivery system (DeRosa et al., 2010), have been exploited for their absorption, translocation, accumulation and particularly effects on growth and yield of crop (Nair et al., 2010). In this concern, Shams and Morsy (2014) on tomato who found that nano NPK produced the highest early fruit yield/feddan.

Concerning the effect of the combined interaction between magnetization and nano potassium particles treatments, data in Table (4) show that the early fruit weight, total fruit weight and total fruit number $/ \mathrm{m}^{2}$ were significantly affected in the first season only. The plants treated with magnetite plus magnetized water and $100 \%$, followed by $75 \%$ nano potassium particles gave the highest values of early and total fruit weight $/ \mathrm{m}^{2}$ compared to the other treatments.

\section{Marketable and non-marketable fruit yield:}

Data presented in Table (5) show that, the magnetite plus magnetized water treatment significantly increased marketable fruit yield as weight and number $/ \mathrm{m}^{2}$, compared to the other treatments in both seasons. On the other hand, the heaviest weight and highest number of non-marketable fruits were obtained from non-magnetic plants treatment. 
Regarding the effect of nano potassium particles treatments on marketable fruit yield as weight and number per $\mathrm{m}^{2}$, data presented in Table (5) clear that cucumber plants treated with $100 \%$ nano potassium particles produced the heaviest weight and the highest number of marketable fruit yield, followed by $75 \%$ nano potassium, bulk potassium and finally those treated with 50 and $25 \%$ nano potassium treatments, respectively. On the other hand, the weight and number $/ \mathrm{m}^{2}$ of non-marketable fruit yield had an opposite trend in both seasons. The treatments had highly significant effect on marketable and non-marketable fruit yield as weight and number $/ \mathrm{m}^{2}$ in both seasons, an exception was obtained with number of non-marketable fruit yield in the first season as the differences were not significant.

As the combined interaction effect of various combinations between magnetization and nano potassium particles treatments, the highest values of weight and number of marketable fruit yield were obtained from the combined treatment of magnetite plus magnetized water and either 100 or $75 \%$ nano potassium particles treatments. On the other hand, the highest non-marketable fruit yield as weight and number was obtained from the non-magnetic plants combined with $25 \%$ nano potassium treatments in both seasons.

\section{Fruit quality:}

Data in Table (6) indicate that fruit length, fruit diameter, soluble solids content and firmness were not significantly affected by magnetization treatments in both seasons, except for fruit soluble solids content in the second season and fruit firmness in the first one as the differences were highly significant. However, magnetization treatments caused an increment of cucumber fruit quality; fruit length, diameter, SSC $\%$ and firmness compared to non-magnetic treatment. The magnetite plus magnetized water treatment tended to give the highest values of fruit quality parameters, followed by magnetized water and magnetite treatments, while the lowest values were obtained from non-magnetic plants in both seasons. In this concern, Rezaiiasl et al., (2012) and Shahin et al., (2016) on cucumber stated that cucumber plants either treated with magnetite or magnetized water increased fruit diameter.

Concerning the effect of nano potassium particles on fruit quality, i.e., fruit length, diameter, soluble solids content and firmness, data in Table (6) demonstrate that there were a highly significant differences among nano potassium treatments in both seasons. The highest records of abovementioned fruit characters were obtained from $100 \%$ nano potassium 
particles, followed by bulk, $75 \%$ nano potassium and finally 50 and $25 \%$ nano potassium in both seasons.

Fruit length, fruit diameter, soluble solid content and fruit firmness were not appreciably affected by the combined interaction between magnetization and nano potassium particles treatments in both seasons. However, the combined interaction treatment of magnetite plus magnetized water and $100 \%$ nano potassium particles had the highest values of abovementioned fruit quality parameters. These increases in fruit quality of cucumber fruits that using magnetization treatments either magnetite or magnetized water may be due to their beneficial effects on vegetative growth characters (Table 3 ).

\section{Leaves chemical content:}

Data presented in Table (7) clear that leaves chemical content, i.e., total green color reading (SPAD), nitrogen, phosphorus and potassium were highly significant affected by magnetization treatments in both seasons. All magnetization treatments had an increment in total green color reading, nitrogen, phosphorus and potassium leaves contents of cucumber plants compared to non-treated ones in both seasons.

The magnetite plus magnetized water treatment gave the highest green color reading and percentage of $\mathrm{N}, \mathrm{P}$ and $\mathrm{K}$ in comparison with the other treatments, while the lowest values were obtained from non-treated plants in both seasons.

In regard to the effect of nano potassium particles, there was a highly significant increase in total green color reading (SPAD), N, P and K (\%) in both seasons, meanwhile, cucumber plants treated with $100 \%$ nano potassium particles gave the highest records of those parameters, followed by either $75 \%$ nano or bulk potassium treatments. On the other hand, the lowest values were produced by using $25 \%$ nano potassium particles in both seasons.

Data in Table (7) show that the effect of magnetization and nano potassium particles combined interaction on total green color reading was not significant in both seasons, except nitrogen and phosphorus in the second one and potassium leaves content in the first one where the differences were highly significant. However, the combined interaction between magnetite plus magnetized water and both $100,75 \%$ nano potassium particles and bulk potassium treatments tended to produce the highest values of both $\mathrm{N}$ and $\mathrm{K}$, while the interaction with 75 or $50 \%$ nano potassium particles gave the highest $\mathrm{P}(\%)$ leaves content in comparison 
with the other treatments in both seasons. These results came in the similar point of view with those reported by Al-Obadi et al., 2012 on cucumber and Abd El-All et al. (2013) on squash, they illustrated that the highest chlorophyll content was obtained from plants which were irrigated with magnetized water.

\section{Economic evaluation:}

Data of economic evaluation in terms of costs, crop value, net income/ $\mathrm{m}^{2}$ and economic efficiency as a result of the combined interaction between magnetization and nano potassium particles treatments of cucumber plants are shown in Table (8) in two experimental seasons of 2014/15 and 2016/17. The results showed that there were differences in costs $/ \mathrm{m}^{2}$ which ranged between 17.3 L.E. for the combined interaction between non-magnetic (control) and $25 \%$ nano potassium particles treatments in the second season $(2016 / 17)$ and 21.25 L.E. for the treatment of combining magnetite plus magnetized water and $100 \%$ nano potassium particles treatments in the first season (2014/15).

Concerning crop value and net income/ $\mathrm{m}^{2}$, data presented in Table (8) clear that the highest values were obtained from the combined interaction between magnetized water or magnetite plus magnetized water and $100 \%$, followed by $75 \%$ nano potassium particles and bulk potassium treatments compared with the combined interaction between non-magnetic (control) and $25 \%$ nano potassium particles treatment which had the lowest values in both seasons.

Respecting the economic efficiency, data in Table (8) clearly show that the combined interaction treatment of magnetized water or magnetite plus magnetized water and $75 \%$ nano potassium particles had the highest records, followed by $100 \%$ nano potassium particles and bulk potassium in both seasons, respectively. On the other hand, the lowest values were obtained from the combined interaction of non-magnetization and $25 \%$ nano potassium particles treatment in both seasons.

Conclusively, it could be recommended that the combination between magnetization with $75 \%$ potassium nano fertilizers was more suitable for obtaining the largest early and total yields with good fruit quality and more profitable for growers and consumers of cucumber grown in the autumn season inside the plastic houses under Kafrelsheikh conditions and similar areas. 


\section{REFERENCES}

Abd El-All, H. M., S. M. Ali and S. M. Shahin (2013). Improvement growth, yield and quality of squash (Cucurbita pepo L.) plant under salinity conditions by magnetized water, amino acids and selenium. $J$. Appl. Sci. Res., 9 (1): 937-944.

Abdul Qados, M. S. and M. Hozayn (2010). Irrigation with magnetized water enhances growth, chemical constituent and yield of chickpea (Cicer arietinum L.). Agric \& Bio. J. of North America, 4: 671-676.

Abou El-Yazied, A., O. A. Shalaby, A. M. El-Gizawy, S. M. Khalf and A. El-Satar (2012). Effect of magnetic field on seed germination and transplant growth of tomato. J. Amer. Sci., 7 (12): 306-312.

Abou-Hadid, A.F. (2010). Climate change and the Egyptian agriculture conundrum. In: Ninth IDDC International Conference of development of dry land: Sustainable development in the dry lands-meeting the challenge of globall climate change. Alexandria, pp. 161-170, November 2008.

Afshar, R. M., H. Hadi and A. Pirzad (2012). Effect of nano-iron foliar application on qualitative and quantitative characteristics of cowpea, under end season drought stress. Int. Res. J. Appl. Basic. Sci., 3 (8): 1709-1717.

Ali, T. B., S. E. Khalil and A. M. Khalil (2011). Magnetic treatments of Capsicum annuиm L. grown under saline irrigation conditions. $J$. Appl. Sci. Res., 7 (11): 1558-1568.

Ali, Y., R. Samaneh and F. Kavakebian (2014). Applications of magnetic water technology in farming and agriculture development: A review of recent advances. Curr. World Environ., 9(3): 695-703.

Al-Obadi, H. S. H., S. A. A. Al-Hamdany and R. W. Mahmood (2012). Effect of irrigation with magnetization water and chelate-iron fertilization on growth and yield of cucumber (Cucumus sativus L.) in plastic house. J. Agric. Sci. Tikrit Univ., 12(4):76-82.

Al-Said, A.M. and A. M. Kamal (2005). Enhancement of growth and yield of eggplant (Solanum melogena L.) by foliar nutrition of potassium citrate and iron-chelate in early summer season. J. Agric. Sci., Mansoura Univ., 30 (12):7863-7869.

A.O.A.C. (1980). Association of Official Agriculture Chemistry. Official Methods Of Analysis, Washington, D.C. $10^{\text {th }}$ ed.

Black, C.A. (1965). Methods Of Soil Analysis. Amer. Soc. Agron. Inc. Madison, Wisconnsin, USA. 
Bogatin, J., N. Bondarenko, E. Gak, E. Rokhinson and J. Ananyen (1999). Magnetic treatment of irrigation water: experimental results and application conditions. Environ. Sci. \& Technol., 33(8): 12801285.

Castiglione, M. R. and R. Cremonini (2009). Nanoparticles and higher plants. Caryologia, 62:161-165.

Chahal, A. S., A. R. Madgulkar, S. J. Kshirsagar, M. R. Bhalekar, A. Dikpati and P. Gawli (2012). Amorphous nanoparticles for solubility enhancement. J. Adv. Pharm. Sci., 2:167-178.

De Rosa, M. C., C. M. M. Schnitzer, R. Walsh and Y. Sultan (2010). Nanotechnology in agriculture. Adv. Nat. Sci. Nanosci. Nanotechnol., 3:10-11.

De Souza, A., D. Garci, L. Sueiro, L. Licea and E. Porras (2006). PreSowing magnetic treatment of tomato seeds increase the growth and yield of plants. Bioelectromagnetiscs, 2: 247-257.

Duarte Diaz, C. E., J. A. Riquenes, B. Sotolongo, M.A. Portuondo, E. O. Quintana and R. Perez (1997). Effects of magnetic treatment of irrigation water on the tomato crop. Hort. Abst., 69, 494.

Duncan, B. D. (1955). Multiple rang and multiple F-test. Biometrics, 11:1-42.

Ekinici, M., A. Dursum, E. Yildirim and F. Parlakova (2014). Effect of nanotechnology liquid fertilizers on the plant growth and yield of cucumber (Cucumis sativus L.). Acta Sci. Pol., Horotum Cultus, 13(3) :135-141.

EI - Eslamboly, A. A. S. A. and M. A. S. Abdel-Wahab (2014). Grafting salinity tolerant rootstocks and magnetic iron treatments for cantaloupe production under conditions of high salinity soil and irrigation water. Middle East J. Agric. Res., 3(3): 677-693.

El-Gizawy, A. M., M. E. Ragab, N. A. S. Helal, A. El- Satar and I. H. Osman (2016). Effect of magnetic field treatments on germination of true potato seeds, seedlings growth and potato tubers characteristics. Middle East J. Agric. Res., 5(1): 1-8.

El-Hifny, I. M. M., M. E. Ramadan, I. I. El-Oksh and M. M. Soliman (2008). Effect of some cultural practices on cauliflower tolerance to salinity under Ras Suder conditions. J. Biol. Chem. \& Environ. Sci., 3(1): 899-913.

Esitken, A. and M. Turan (2004). Alternating magnetic field effects on yield and plant nutrient element composition of strawberry (Fragaria $x$ ananassa cv. Camarosa). Acta Agriculturae Scandinavica, 54:135139. 
Fleischer A., M.A. ONeill, R. Ehwald (1999). The pore size of nongraminaceous plant cell wall is rapidly decreased by borate ester cross-linking of the pectic polysaccharide rhamnoga- lacturonan II. Plant Physiol., 121:829-838.

Gabrielli, C., R. Jaouhari, G. Maurin and M. Keddam (2001). Magnetic water treatment for scale prevention. Water Res., 35: 3249-3259.

Ghahremani, A., K. Akbari, M. Yousefpour and H. Ardalani (2014). Effects of Nano-Potassium and Nano-Calcium Chelated Fertilizers on Qualitative and Quantitative Characteristics of Ocimum basilicum. International Journal for Pharmaceutical Research Scholars, 3(12):235-241.

Jackson, M.L. (1967). Soil Chemical Analysis. Prentic-Hall of India, Private Limited, New Delhi, pp.115.

John, P. D. and O. Frank (1987). Production Economics Theory With Applications. Second Edition -library of Congress cataloging in publication data U.S.A., New York.

Khalil, S. E. and B. H. Abou Leila (2016). Effect of magnetic treatment in improving growth, yield and fruit quality of Physalis pubescens plant grown under saline irrigation conditions. Int. J. Chem. Tech. Res., 9(12):246-258.

King, E.J. (1951). Micro-Analysis In Medical Biochemistry. $2^{\text {nd }}$ ed. Churchill, London.

Little, T.A. and F.J. Hills (1972). Statistical Methods In Agriculture Research. Calif. Univ., Davis, p. 242.

Maheshwari, B. L. (2009). Magnetic treatment of irrigation water: evaluation of its effects on vegetable crop yield and water productivity. Ph.D Thesis. University of Western Sydney, School of Environ., and Agriculture.

Maheshwari, B.L. and H. S. Grewal (2009). Magnetic treatment of irrigation water: Its effects on vegetable crop yield and water productivity. Agric. Water Manage., 96:1229-1236.

Maheshwari, B.L. and H. S. Grewal (2011). Magnetic treatment of irrigation water and snow pea and chickpea seeds enhances early growth and nutrient contents of seedlings. Bio electromagnetics, 32: (1):58-65.

Malkoti M.G. (1999). Comprehensive detection method and the need to optimize the use of chemical fertilizers. Fifth Edition. Tarbiat Modarres University Press. Tehran. Iran. 
Mansour, E. R. (2007). Effect of some culture practices on cauliflower tolerance to salinity under Ras Suder conditions. M.Sc. Thesis, Fac. Agric., Ain Shams Univ., Egypt.

Marquard, R. D. and J. L. Timpton (1987). Relationship between extractable chlorophyll and an insites method to estimate leaf green. Hort. Science, 22 (6): 1327.

Ministry of Agriculture and Land Reclamation (1990). Agriculture Research Center-Protected Agriculture Project. Technical Bulletin. No. 3. Vegetables nutrient under protected cultivation. pp. 106.

Ministry of Agriculture and Land Reclamation (2016). Bulletin of the agriculture statistics, part 2, Summer \& Nili crops, p.198.

Moraru, C. I., C. P. Panchapakesan, Q. R. Huang, P. Takhistov, L. Sean and J. L. Kokini (2003). Nanotechnology - A new frontier in food science. Food Technology, 57 (12):24-29.

Nair, R., S. H. Varghese, B. G. Nair, T. Maekawa, Y. Yoshida and D. S. Kumar (2010). Nanoparticulate material delivery to plants. Plant Sci., 179 (3): 154-163.

Pregel, F. (1945). Quantitative Organic Micro Analysis. $4^{\text {th }}$ ed. J. \& A. Churchill, Lotoi, London.

Racuciu, M. and D. Creanga (2006). TMA-OH coated magnetic nanoparticles internalize in vegetal tissue. Romanian J. Phys., 52:395-402.

Rezaiiasl, A., A. Ghasemnezhad and S. Shahabi (2012). Study the response of cucumber plant to different magnetic fields. Journal of Advanced Laboratory Research in Biology, 3(1):42-46.

Shahin, M. M., A. M. A. Mashhour and E. S. E. Abd-Elhady (2016). Effect of magnetized irrigation water and seeds on some water properties, growth parameter and yield productivity of cucumber plants. Curr. Sci. Int., 5(2):152-164.

Shams, A. S. and N. M. Morsy (2014). Response of tomato plants to low plastic-Zno nano composite tunnels covering and chitosan nano particles foliar spraying. J. Plant Prod., Mansoura Univ., 5(9): 1533-1545.

Shehata, S. A., Y. M. Ahmed, Y. T. Emam and M. A. Azoz (2012). Influence of some organic and inorganic fertilizers on vegetative growth, yield and yield components of cucumber plants. Res. J. Agric. \& Biol. Sci., 8(2): 108-114.

Soliman, A. S., M. Hassan, F. Abou Elella, A. H. H. Ahmed and S. A. El-Feky (2016). Effect of nano and molecular phosphorus fertilizers on growth and chemical composition of Baobab (Adansonia digitata L.). J. Plant Sci., 11(4): 52-60. 
Sudhakar, P. C., R. S. Chandel and S. kalyan (2002). Effect of sulphar, iron and silicon on the growth and yield of irrigated mustard. Annals of Agric. Res., 23 (3) 483-485.

Surendran U., O. Sandeep and E. J. Joseph (2016). The impacts of magnetic treatment of irrigation water on brinjal plant, water and soil characteristics. Agric. Water Manag., 178: 21-29.

Tai, C.Y., C.K. Wu and M. C. Chang (2008). Effects of magnetic field on the crystallization of $\mathrm{CaCO}_{3}$ using permanent magnets. Chem. Engin. Sci., 63:5606-5612.

Tantawy, A. S., A. M. R. Abdel- Mawgoud, M. F. Zaki and S. A. Saleh (2016). Amelioration of salinity negative effects on two hybrids of cantaloupe by nano potassium application. Int. J. Pharm Tech. Res., 9(12): 317-326

Tantawy, A. S., Y. A. M. Salama, M. A. El-Nemr and A. M. R. AbdelMawgoud (2015). Nano silicon application improves salinity tolerance of sweet pepper plants. Int. J. Chem. Tech. Res., 8(10): 11-17.

Usherwood, N.R. (1985). The role of potassium in crop quality. In Munson, R. D. (ed). Potassium in agriculture ASA-CSSA-SSSA, Madison, WI. pp. 489-513.

Wang, H. (2008). Method for preparing bio-organic fertilizer by use of peat with high fertilizer efficiency.CN 101255072.

Yadava, U.L. (1986). A rapid and non- destructive method to determine chlorophyll in intact leaves. Hort Science, 21:1449.

Yano, A., Y. Ohashi, T. Hirasaki and K. Fujiwara (2004). Effects of 60 $\mathrm{Hz}$ magnetic field on photosynthetic uptake and early growth of radish seedlings. Biol. Electromagnetics, 25 (8): 572-581.

Yiunan, Y., L. Yuan, Y. Yongqing and L. Chunyang (2005). Effect of seed pretreatment by magnetic field on the sensitivity of cucumber (Cucumis sativus) seedlings to ultraviolet-B radiation. Environmental and Experimental Botany, 54:286-294.

Zambryski, P. (2004). Cell-to-cell transport of proteins and fluorescent tracers via plasmodesmata during plant development. The Journal of Cell Biology, 162 (2): 165-168. 


\section{تأثير المغنطة والبوتاسيوم فى صورة جزيئات النانو على النمو والمحصول وجودة ثمار الخيار تحت ظروف فئ الصوبة البلاستيكية}

عبد الشفيق اسماعيل الزعويلى'، محمد بسيونى اسماعيل الصاوى'، السماحى محمود

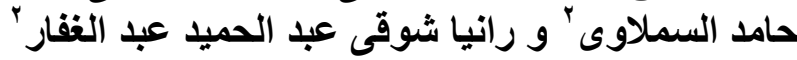

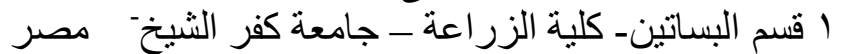

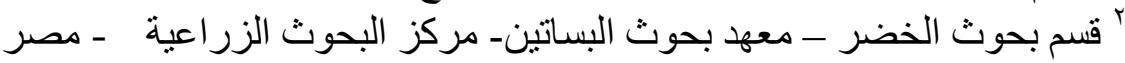

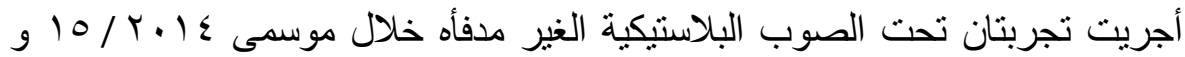

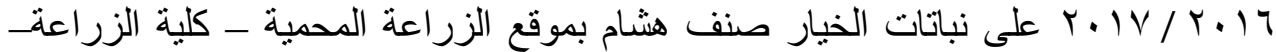

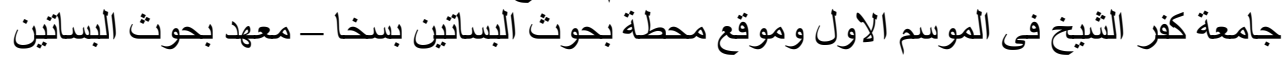

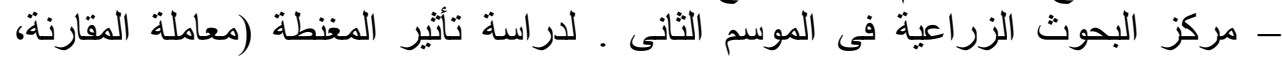

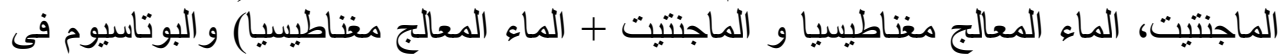

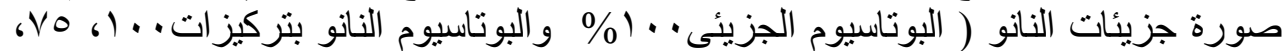

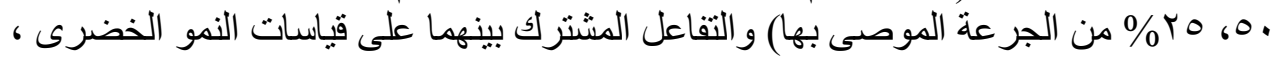
محصول الثمار ومكوناته، جودة الثمار و المحتوى الكيماوى للأور اقت. يمكن تلخيص النتائج كما يلى: الئل

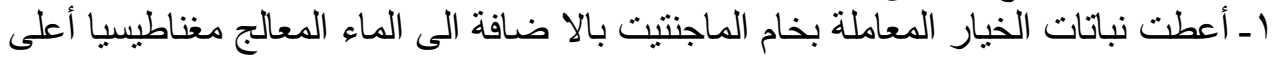

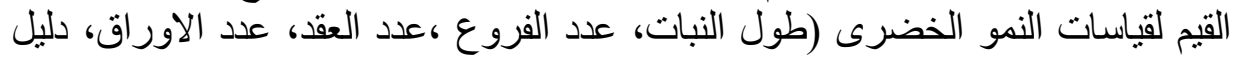

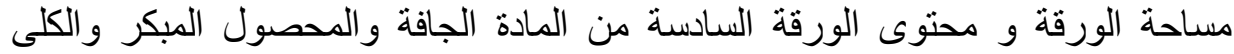

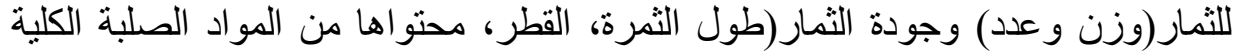

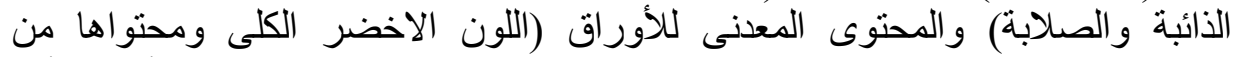
النيتروجين و الفسفور و البوتاسيوم) مقارنة بالنباتات الغير معاملة (المقارنة) التى أعطت أقلى التصن

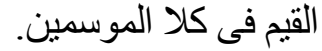

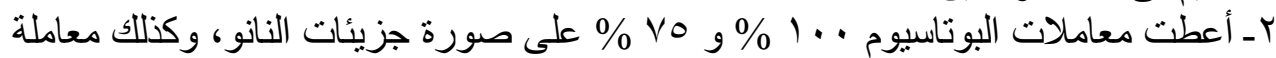

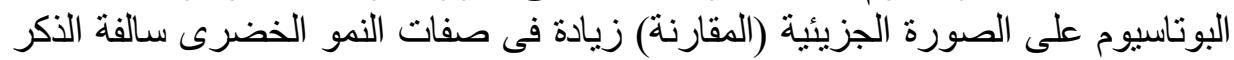

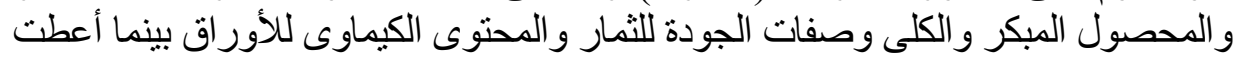

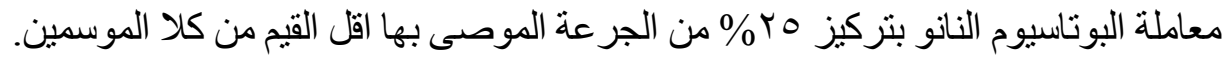

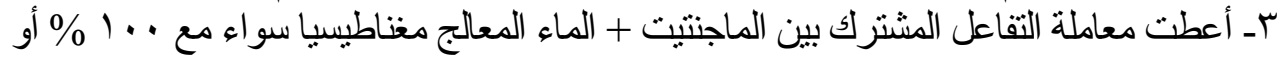

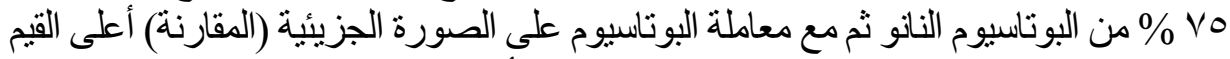

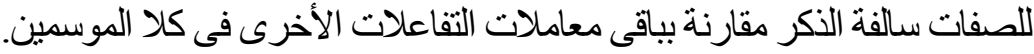

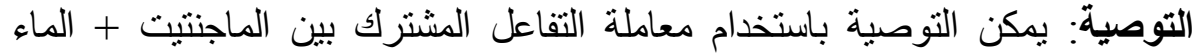

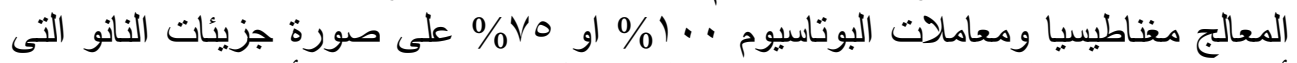

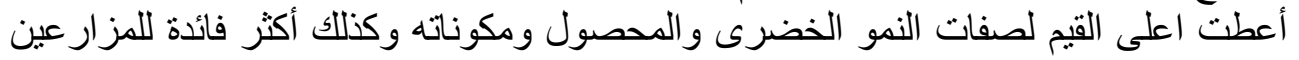

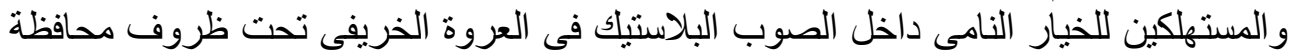
كفر الثيخ و المناطق المشابهة مقارنة بباقى المعاملات. 